\title{
Tinjauan Durabilitas Campuran Asphalt Concrete Wearing Course Menggunakan Aspal Tua Dengan Berbagai Bahan Peremaja
}

\author{
Review on Durability of Asphalt Concrete Wearing Course Using \\ Aged Asphalt with Various Rejuvenating Agent
}

\author{
Ratna Yuniarti *, Desi Widianty, Rohani, Hasyim \\ Jurusan Teknik Sipil Fakultas Teknik Universitas Mataram, INDONESIA. Tel. +62-0370 636126 \\ *corresponding author, email: ratna_yuniarti@unram.ac.id
}

Manuscript received: 06-02-2020. Accepted: 03-07-2020

\begin{abstract}
ABSTRAK
Asphalt concrete wearing course berada pada bagian teratas pada lapis perkerasan jalan sehingga langsung terkena paparan sinar matahari dan pengaruh lingkungan lainnya. Tingginya temperatur pada permukaan jalan serta oksidasi mempercepat penuaan aspal menjadi kaku dan rapuh. Proses penuaan mengakibatkan berkurangnya ikatan antara aspal dan agregat sehingga menimbulkan berbagai jenis kerusakan. Aspal yang telah mengalami penuaan dapat digunakan kembali untuk mengurangi pemakaian material baru pada pekerjaan rehabilitasi jalan dengan menambahkan bahan peremaja. Tulisan ini ingin mengkaji durabilitas (keawetan) dari campuran aspal concrete wearing course menggunakan aspal tua yang telah diremajakan dengan bahan peremaja minyak jelantah, minyak tanah dan oli bekas serta resin epoxy. Penuaan aspal dilakukan dengan pemanasan pada suhu $85^{\circ} \mathrm{C}$ selama 120 jam (long term oven aging). Durabilitas diukur dari nilai Marshall immersion yang menunjukkan daya tahan campuran terhadap rendaman air serta hubungan antara Marshall immersion dengan nilai rongga dalam campuran (VIM), rongga di antara mineral agregat (VMA), rongga yang terisi aspal (VFB) dan density (kepadatan). Berdasarkan analisa yang dilakukan disimpulkan bahwa penggunaan bahan peremaja minyak jelantah, minyak tanah dan oli bekas serta resin epoxy dapat meningkatkan durabilitas dari campuran aspal yang telah mengalami penuaan.
\end{abstract}

Kata kunci: aspal tua; bahan peremaja; minyak jelantah; resin epoxy; minyak tanah; oli bekas

\begin{abstract}
Asphalt concrete wearing course is laid on the top of road pavement so that directly exposed to ultra violet light and other environment impact. The higher temperature at the pavement surface and exposure to atmospheric oxygen accelerated aging cause asphalt to stiffen and become brittle. This aging result decrease the binding of asphalt and aggregate leads various damage of pavement. The aged asphalt rejuvenated and recycled with rejuvenating agent has been developed to reduce the use of virgin material for road maintenance. This article aims to review durability of asphalt concrete wearing course using waste cooking oil, epoxy resin, kerosene and waste engine oil as asphalt rejuvenators. Aging
\end{abstract}


asphalt was prepared by heating in an oven at $85{ }^{\circ} \mathrm{C}$ for 120 hours (long term oven aging). Durability was assessed from the value of Marshall immersion which represent the resistance of asphalt mixture at water immersion. Relation between Marshall immersion and voids in mix (VIM), voids in the mineral aggregate (VMA), voids filled with bitumen (VFB) and density are also evaluated. From the analysis, it can be concluded that the use of waste cooking oil, epoxy resin, kerosene and waste engine oil as asphalt rejuvenators increase the durability of asphalt mixture containing the aged asphalt.

Key words: aged asphalt; rejuvenating agent; waste cooking oil; epoxy resin; kerosene; waste engine oil

\section{PENDAHULUAN}

Kerusakan yang terjadi pada konstruksi jalan raya sebelum tercapainya umur layanan yang direncanakan antara lain disebabkan oleh penuaan pada bahan perkerasan jalan akibat pengaruh cuaca. Paparan sinar matahari dan kelembaban menyebabkan sifat elastisitas aspal menjadi berkurang. Aspal yang kaku dan rapuh mengakibatkan berkurangnya ikatan antara aspal dengan agregat sehingga menimbulkan berbagai jenis kerusakan. Untuk mengatasi kerusakan pada perkerasan jalan umumnya dilakukan dengan penambahan lapisan baru di atas perkerasan lama (overlay). Overlay ini memerlukan biaya yang cukup besar karena harga aspal dan agregat semakin mahal akibat meningkatnya kebutuhan aspal dan agregat untuk pembangunan dan pemeliharaan jalan.

Untuk mengurangi ketergantungan pada aspal dan agregat, material tersebut dapat digunakan kembali setelah melalui proses tertentu atau dikenal dengan daur ulang perkerasan jalan (asphalt pavement recycling). Teknik daur ulang dilaksanakan dengan menggunakan mesin yang menggaruk permukaan jalan sampai kedalaman tertentu, menggemburkan, mencampurnya secara panas ataupun dingin dengan penambahan aspal, agregat dan aspal modifier, kemudian menggelarnya di atas jalan lama. Teknik daur ulang lebih menguntungkan dibandingkan dengan overlay karena penghematan kebutuhan material baru, elevasi permukaan jalan tidak berubah signifikan, ketinggian trotoar dan median jalan tidak perlu disesuaikan serta lebih terpeliharanya kelestarian lingkungan dan alam (Soedarmanto dan Dardak, 1991).

Agar dapat digunakan kembali, aspal yang telah mengalami penuaan perlu diremajakan dengan bahan peremaja (rejuvenating agent). Bahan peremaja tersebut antara lain adalah limbah minyak wijen, limbah minyak kedelai, limbah minyak jagung, limbah minyak sawit, limbah minyak kacang tanah, minyak biji nyamplung, minyak biji jarak, minyak jelantah, getah pinus dan bahan alami lainnya (Bailey and Philips, 2010; Yuniarti, 2014; Ahmad et al., 2017; Xinxin et al., 2018; Yuniarti, 2019).

Sampel aspal yang telah mengalami penuaan dapat diambil langsung di lapangan dengan pengeboran (core drill) sebagaimana yang dilakukan pada tahapan pekerjaan daur ulang perkerasan jalan. Brown and Scholz (2000) menyimpulkan bahwa aspal baru (virgin asphalt) yang dipanaskan pada suhu $85^{\circ} \mathrm{C}$ selama 120 jam (long term oven aging) dianggap mengalami penuaan yang setara dengan penuaan jangka panjang secara alami di United Kingdom. Brown and Scholz (2000) juga menyimpulkan bahwa long term oven aging pada sampel campuran padat merepresentasikan penuaan secara alami selama 15 tahun di United States. 
Durabilitas (keawetan) adalah kemampuan dari campuran untuk menahan keausan akibat pengaruh cuaca, air dan perubahan suhu. Mengingat umur layanan jalan sangat tergantung dari durabilitas campuran aspal-agregat, maka tulisan ini ingin mengkaji sifat durabilitas dari campuran tersebut. Sifat durabilitas dari campuran asphalt concrete wearing course yang dikaji menggunakan aspal tua melalui penuaan long term oven aging dengan bahan peremaja minyak jelantah, minyak tanah dan oli bekas serta resin epoxy.

\section{BAHAN DAN METODE}

Pengkajian terhadap sifat durabilitas campuran asphalt concrete wearing course ini mengacu pada hasil penelitian yang dilakukan oleh Huriyati (2018), Fathiah (2019) dan Pratiwi (2019) di Laboratorium Transportasi dan Rekayasa Jalan Raya Jurusan Teknik Sipil Fakultas Teknik Universitas Mataram. Pengujian tersebut menggunakan aspal penetrasi 60/70 yang dituakan melalui pengovenan selama 120 jam pada suhu $85{ }^{\circ} \mathrm{C}$. Aspal yang mengalami penuaan ditambahkan bahan peremaja minyak jelantah, minyak tanah dan oli bekas serta resin epoxy dengan prosentase tertentu untuk mengembalikan kualitas aspal tersebut sehingga dapat digunakan kembali sebagaimana prinsip daur ulang perkerasan jalan.

Minyak jelantah yang berwarna coklat pekat digunakan sebagai bahan peremaja aspal tua setelah dicampur dengan sari buah mengkudu dengan perbandingan 2 bagian minyak jelantah dan 1 bagian sari buah mengkudu dengan tujuan untuk menjernihkan minyak jelantah tersebut. Prosentase bahan peremaja minyak jelantah yang digunakan adalah $1.5 \% ; 2 \%$ dan $2.5 \%$ terhadap berat aspal tua. Adapun prosentase resin epoxy adalah $0.3 \% ; 0.5 \% ; 0.7 \%$ dan $0.9 \%$ terhadap berat aspal tua, sedangkan minyak tanah dan oli bekas dicampurkan dengan perbandingan $75 \%$ minyak tanah dan $25 \%$ oli bekas dengan prosentase $3 \%, 4 \%, 5 \%$ dan $6 \%$ terhadap berat aspal tua.

Agregat kasar dan agregat halus yang diambil dari stok agregat di pabrik pencampur aspal (asphalt mixing plant) di Pringgabaya, Lombok Timur. Prosedur penelitian agregat, aspal serta campuran aspal-agregat berpedoman pada Standar Nasional Indonesia (SNI).

Adapun distribusi ukuran partikel agregat yang digunakan ditampilkan pada Tabel 1.

Tabel 1. Distribusi ukuran agregat yang digunakan

\begin{tabular}{|c|c|c|c|}
\hline No. Saringan & $\begin{array}{c}\text { Ukuran } \\
\text { saringan } \\
(\mathbf{m m})\end{array}$ & $\begin{array}{l}\text { Spesifikasi*) } \\
\text { (\% lolos) }\end{array}$ & $\begin{array}{cc}\text { Gradasi } & \text { yang } \\
\text { digunakan**) } & \\
(\% \text { lolos }) & \end{array}$ \\
\hline $3 / 4 "$ & 19 & 100 & 100 \\
\hline $1 / 2 "$ & 12.5 & $90-100$ & 95 \\
\hline $3 / 8 "$ & 9.5 & $77-90$ & 84 \\
\hline No. 4 & 4.75 & $53-69$ & 61 \\
\hline No. 8 & 2.36 & $33-53$ & 43 \\
\hline No. 16 & 1.18 & $21-40$ & 31 \\
\hline No. 30 & 0.6 & $14-30$ & 22 \\
\hline No. 50 & 0.3 & $9-22$ & 16 \\
\hline No. 100 & 0.15 & $6-15$ & 11 \\
\hline No. 200 & 0.075 & $4-9$ & 7 \\
\hline
\end{tabular}

Sumber: *) Direktorat Jenderal Bina Marga (2018)

**) Huriyati (2018), Fathiah (2019), Pratiwi (2019) 
Pencampuran aspal-agregat dilakukan secara panas (hotmix) pada suhu $155^{\circ} \mathrm{C}$ menggunakan kadar aspal optimum 6\% sedangkan proses pemadatan dilakukan sebanyak 75 kali dengan alat pemadat Marshall pada masing-masing sisinya. Hubungan antara rongga dalam campuran (voids in mix = VIM), rongga di antara mineral agregat (voids in the mineral aggregate $=\mathrm{VMA}$ ), rongga yang diselimuti aspal (voids filled with bitumen $=\mathrm{VFB}$ ) dan density (kepadatan) dengan nilai Marshall immersion digunakan sebagai tolok ukur untuk menentukan tingkat durabilitas (keawetan) pada campuran asphalt concrete wearing course.

\section{HASIL DAN PEMBAHASAN}

Hasil pengujian agregat yang digunakan disajikan pada Tabel 2, sedangkan hasil pengujian aspal 60/70 dan aspal yang dituakan disajikan pada Tabel 3.

Tabel 2. Hasil pengujian agregat

\begin{tabular}{|c|c|c|c|c|}
\hline \multirow{2}{*}{\multicolumn{2}{|c|}{ Jenis pengujian }} & Agregat & \multirow{2}{*}{$\begin{array}{l}\begin{array}{r}\text { Agregat } \\
\text { halus*) }\end{array} \\
\end{array}$} & \multirow{2}{*}{$\begin{array}{l}\text { Persyarat } \\
\text { an**) }\end{array}$} \\
\hline & & kasar*) & & \\
\hline & Keausan impact (\%) & 25.76 & - & Maks. 30 \\
\hline & Berat jenis bulk & 2.671 & 2.990 & Min. 2.5 \\
\hline & Berat jenis semu & 2.773 & 3.217 & Min. 2.5 \\
\hline & Penyerapan terhadap air $(\%)$ & 1.379 & 2.364 & Maks. 3 \\
\hline (\%) & Kelekatan agregat terhadap aspal & 97 & - & Min. 95 \\
\hline
\end{tabular}

Tabel 3. Hasil pengujian aspal 60/70 dan aspal tua

\begin{tabular}{|c|c|c|c|c|c|c|c|}
\hline \multirow[b]{2}{*}{$\begin{array}{l}\text { Jenis } \\
\text { pengujian }\end{array}$} & \multicolumn{2}{|c|}{ Aspal 60/70 } & \multicolumn{4}{|c|}{ Aspaltua } & \multirow[b]{2}{*}{$\begin{array}{l}\text { Persyarat } \\
\text { an } \\
* * * *)\end{array}$} \\
\hline & $\begin{array}{l}\text { Hasil } \\
\text { pengujian } \\
*)\end{array}$ & $\begin{array}{l}\text { Hasil } \\
\text { pengujian } \\
* *)\end{array}$ & $\begin{array}{l}\text { Hasil } \\
\text { pengujian } \\
* * *)\end{array}$ & $\begin{array}{l}\text { Hasil } \\
\text { pengujian } \\
*)\end{array}$ & $\begin{array}{l}\text { Hasil } \\
\text { pengujian } \\
* *)\end{array}$ & $\begin{array}{l}\text { Hasil } \\
\text { pengujian } \\
* * *)\end{array}$ & \\
\hline $\begin{array}{l}\text { Penetrasi }(0.1 \\
\mathrm{mm})\end{array}$ & 61.2 & 70.7 & 65 & 28.06 & 29.53 & 26.1 & $60-79$ \\
\hline $\begin{array}{l}\text { Titik lembek } \\
\left({ }^{\circ} \mathrm{C}\right)\end{array}$ & 50.4 & 52.3 & 50.5 & 58.5 & 62.3 & 58.5 & $>48$ \\
\hline $\begin{array}{l}\text { Titik nyala } \\
\left({ }^{\circ} \mathrm{C}\right)\end{array}$ & $>300$ & $>300$ & $>300$ & $>300$ & $>300$ & $>300$ & $>232$ \\
\hline $\begin{array}{l}\text { Daktilitas } \\
(\mathrm{cm})\end{array}$ & 165 & 141.1 & 133.5 & 97.4 & 88.3 & 81.5 & $>100$ \\
\hline Berat jenis & 1.04 & 1.03 & 1.045 & 1.035 & 1.026 & 1.018 & $>1.00$ \\
\hline
\end{tabular}

Berdasarkan Tabel 2, agregat yang digunakan memenuhi persyaratan baik daya tahan agregat terhadap degradasi, kelekatan terhadap aspal maupun berat jenisnya. Sesuai dengan yang disajikan pada Tabel 3, terlihat bahwa nilai penetrasi aspal tua berada pada rentang 26.1 - $28.06(0.1 \mathrm{~mm})$. Sebagai material yang berasal dari sisa penyulingan minyak bumi, tingkat kekentalan aspal sangat tergantung dari kandungan oil di dalamnya (Porto et al., 2019). Setelah dioven selama 120 jam pada suhu $85^{\circ} \mathrm{C}$, kandungan oil pada aspal menjadi berkurang. Proses oksidasi dan penguapan menyebabkan terjadinya pengerasan terkait sifat termoplastik aspal 
(Fordyce and O'Donnell, 1994). Proses oksidasi meningkatkan viskositas aspal sehingga nilai penetrasi aspal menjadi rendah yang menunjukkan bahwa aspal menjadi keras dan kaku. Karena kekakuan tersebut, maka aspal menjadi cepat putus ketika dilakukan pengujian daktilitas (Suroso, 2009). Aspal yang bersifat keras, kaku dan rapuh secara otomatis akan sulit meleleh sehingga titik lembek aspal tua lebih tinggi dari aspal 60/70. Ditinjau dari berat jenis, aspal yang dioven selama 120 jam pada suhu $85^{\circ} \mathrm{C}$ mengalami kehilangan berat akibat penguapan sehingga berat jenisnya menjadi lebih kecil dari aspal 60/70. Adapun hasil pengujian aspal tua yang telah diremajakan dengan bahan peremaja disajikan pada Tabel 4.

Tabel 4. Hasil pengujian aspal tua dengan penambahan bahan peremaja

\begin{tabular}{lccccccccccc}
\hline \multirow{2}{*}{$\begin{array}{l}\text { Jenis } \\
\text { pengujian }\end{array}$} & \multicolumn{3}{c}{$\begin{array}{c}\text { Peremaja } \\
\text { Minyak jelantah*) }\end{array}$} & \multicolumn{3}{c}{$\begin{array}{c}\text { Peremaja } \\
\text { resin epoxy**) }\end{array}$} & \multicolumn{4}{c}{$\begin{array}{c}\text { Peremaja minyak tanah } \\
\text { dan oli bekas***) }\end{array}$} \\
\cline { 2 - 12 } & $\mathbf{1 . 5 \%}$ & $\mathbf{2 . 0 \%}$ & $\mathbf{2 . 5 \%}$ & $\mathbf{0 . 3 \%}$ & $\mathbf{0 . 5 \%}$ & $\mathbf{0 . 7 \%}$ & $\mathbf{0 . 9 \%}$ & $\mathbf{3 . 0 \%}$ & $\mathbf{4 . 0 \%}$ & $\mathbf{5 . 0 \%}$ & $\mathbf{6 . 0 \%}$ \\
\hline $\begin{array}{l}\text { Penetrasi } \\
(0.1 \mathrm{~mm})\end{array}$ & 64.6 & 66.8 & 75.9 & 60.1 & 62.9 & 63.1 & 65.1 & 62.3 & 64.2 & 65.3 & 68.4 \\
$\begin{array}{l}\text { Titik } \\
\text { lembek }\left({ }^{\circ} \mathrm{C}\right)\end{array}$ & 53.1 & 51.3 & 51.1 & 56.2 & 54.2 & 54 & 53.7 & 53.5 & 52.5 & 51 & 50.5 \\
$\begin{array}{l}\text { Titik nyala } \\
\left({ }^{\circ} \mathrm{C}\right)\end{array}$ & $>300$ & $>300$ & $>300$ & $>300$ & $>300$ & $>300$ & $>300$ & $>300$ & $>300$ & $>300$ & $>300$ \\
$\begin{array}{l}\text { Daktilitas } \\
(\mathrm{cm})\end{array}$ & 135.3 & 144 & 145 & 146 & 147.2 & 148.5 & 149.8 & 111 & 114 & 116.5 & 118.5 \\
Berat jenis & 1.055 & 1.079 & 1.101 & 1.035 & 1.037 & 1.042 & 1.044 & 1.034 & 1.040 & 1.063 & 1.071 \\
\hline Sub
\end{tabular}

Sumber: *) Huriyati (2018), **) Fathiah (2019), ***) Pratiwi (2019)

Sesuai Tabel 4, penggunaan bahan peremaja minyak jelantah, minyak tanah dan oli bekas serta resin epoxy dapat mengembalikan sifat-sifat fisik aspal sehingga dapat digunakan kembali sebagai bahan pengikat pada campuran aspal-agregat. Hal ini sejalan dengan penelitian Asli et al. (2012) bahwa ditinjau dari nilai penetrasi, titik lembek dan viskositas, tidak ada perbedaan yang signifikan antara sifat fisik aspal asli dengan aspal yang diremajakan dengan peremaja minyak jelantah. Beberapa penelitian juga menyebutkan bahwa kinerja aspal dapat meningkat secara signifikan dengan penggunaan resin epoxy (Cong et al., 2011; Qian et al., 2007; Yang et al., 2007; Chen et al., 2010).

Hasil pengujian campuran asphalt concrete wearing course menggunakan aspal 60/70 dan aspal tua pada kadar aspal optimum 6\% disajikan pada Tabel 5.

Tabel 5. Hasil pengujian campuran menggunakan aspal 60/70 dan aspal tua

\begin{tabular}{|c|c|c|c|c|c|c|c|}
\hline \multirow[b]{2}{*}{$\begin{array}{l}\text { Jenis } \\
\text { pengujian }\end{array}$} & \multicolumn{3}{|c|}{ Aspal 60/70 } & \multicolumn{3}{|c|}{ Aspaltua } & \multirow[b]{2}{*}{$\begin{array}{l}\text { Persyaratan } \\
* * * *)\end{array}$} \\
\hline & $\begin{array}{c}\text { Hasil } \\
\text { pengujian } \\
*)\end{array}$ & $\begin{array}{c}\text { Hasil } \\
\text { pengujian } \\
* *)\end{array}$ & $\begin{array}{c}\text { Hasil } \\
\text { pengujian } \\
* * *)\end{array}$ & $\begin{array}{c}\text { Hasil } \\
\text { pengujian } \\
*)\end{array}$ & $\begin{array}{c}\text { Hasil } \\
\text { pengujian } \\
* *)\end{array}$ & $\begin{array}{c}\text { Hasil } \\
\text { pengujian } \\
* * *)\end{array}$ & \\
\hline VIM (\%) & 4.89 & 4.57 & 4.21 & 5.87 & 5.14 & 4.44 & $3-5$ \\
\hline VMA (\%) & 17.62 & 15.08 & 15.18 & 18.53 & 16.03 & 15.92 & Min. 15 \\
\hline VFB $(\%)$ & 72.31 & 69.70 & 72.28 & 68.35 & 67.94 & 72.15 & Min. 65 \\
\hline $\begin{array}{l}\text { Density } \\
\left(\mathrm{gr} / \mathrm{cm}^{3}\right)\end{array}$ & 2.487 & 2.465 & 2.480 & 2.459 & 2.443 & 2.479 & - \\
\hline $\begin{array}{l}\text { Marshall im- } \\
\text { mersion }(\mathrm{kg})\end{array}$ & 1557.93 & 1788.19 & 2372.13 & 1309.86 & 1564.67 & 2034.48 & - \\
\hline
\end{tabular}

Sumber: *) Huriyati (2018), **) Fathiah (2019), ***) Pratiwi (2019) ****) Direktorat Jenderal Bina Marga (2018) 
Tabel 6. Hasil pengujian campuran aspal tua dengan penambahan bahan peremaja

\begin{tabular}{lccccccccccc}
\hline \multirow{2}{*}{$\begin{array}{l}\text { Jenis } \\
\text { pengujian }\end{array}$} & \multicolumn{3}{c}{$\begin{array}{c}\text { Peremaja } \\
\text { minyak jelantah*) }\end{array}$} & \multicolumn{4}{c}{$\begin{array}{c}\text { Peremaja } \\
\text { resin epoxy**) }\end{array}$} & \multicolumn{4}{c}{$\begin{array}{c}\text { Peremaja minyak tanah } \\
\text { dan oli bekas**) }\end{array}$} \\
\cline { 2 - 12 } & $\mathbf{1 . 5 \%}$ & $\mathbf{2 . 0 \%}$ & $\mathbf{2 . 5 \%}$ & $\mathbf{0 . 3 \%}$ & $\mathbf{0 . 5 \%}$ & $\mathbf{0 . 7 \%}$ & $\mathbf{0 . 9 \%}$ & $\mathbf{3 . 0} \%$ & $\mathbf{4 . 0} \%$ & $\mathbf{5 . 0 \%}$ & $\mathbf{6 . 0 \%}$ \\
\hline VIM (\%) & 5.38 & 5.00 & 4.85 & 4.60 & 4.09 & 3.53 & 3.52 & 4.29 & 4.26 & 4.14 & 4.11 \\
VMA \%) & 17.86 & 17.25 & 16.86 & 16.00 & 15.99 & 15.96 & 15.95 & 15.60 & 15.51 & 15.14 & 15.02 \\
VFB (\%) & 69.91 & 71.03 & 71.30 & 71.24 & 74.44 & 77.90 & 77.94 & 72.53 & 72.57 & 72.68 & 72.69 \\
$\begin{array}{l}\text { Density } \\
\text { (gr/cm }\end{array}$ & 2.480 & 2.496 & 2.509 & 2.458 & 2.469 & 2.481 & 2.485 & 2.483 & 2.484 & 2.487 & 2.502 \\
$\begin{array}{l}\text { Marshall } \\
\text { immersion } \\
(\mathrm{kg})\end{array}$ & 1456.5 & 1581.5 & 1653.8 & 1626.1 & 1654.5 & 1681.4 & 1692.9 & 2402.6 & 2531.6 & 2693.5 & 2724 \\
\hline
\end{tabular}

Sumber: *) Huriyati (2018), **) Fathiah (2019), ***) Pratiwi (2019)

****) Direktorat Jenderal Bina Marga (2018)

Berdasarkan Tabel 5, campuran asphalt concrete wearing course yang menggunakan aspal tua umumnya tidak memenuhi spesifikasi ditinjau dari nilai rongga dalam campuran (VIM). Nilai VIM berkaitan dengan keawetan campuran. Menurut Direktorat Jenderal Bina Marga (2018), nilai VIM dibatasi pada rentang 3-5\%. Nilai VIM yang lebih besar dari 5\% akan mempercepat kerusakan pada perkerasan karena air akan mudah masuk ke dalam rongga tersebut. Air yang mengisi rongga pori dalam campuran akan memperlemah ikatan antara aspal dan agregat sehingga menimbulkan berbagai jenis kerusakan seperti pengelupasan agregat, retak, amblas, dan sebagainya (Mardianus, 2013).

Sebagaimana yang disajikan pada Tabel 6, penggunaan peremaja minyak jelantah dengan rentang 1.5\%-2.5\% menurunkan nilai VIM dari 5.87\% menjadi 5.38\%-4.85\%. Resin epoxy dapat menurunkan nilai VIM menjadi 4.6\%-3.52\%, sedangkan minyak tanah dan oli bekas menurunkan nilai VIM dengan rentang 4.29\%-4.11\%. Penurunan nilai VIM pada rentang 35\% memenuhi spesifikasi karena rongga dalam campuran masih dapat menampung aspal akibat pemadatan lanjutan dari beban lalu lintas dan ketika aspal meleleh akibat kenaikan temperatur perkerasan (Direktorat Jenderal Bina Marga, 2018). Ditinjau dari nilai VMA, penggunaan ketiga jenis bahan peremaja tersebut menurunkan nilai rongga di antara mineral agregat. Bahan peremaja minyak jelantah, minyak tanah dan oli bekas serta resin epoxy dapat melunakkan aspal yang telah kaku sehingga pengikatan yang terjadi antara aspal dan agregat menjadi lebih kuat. Semakin kuat ikatan antara aspal dan agregat, maka campuran yang dihasilkan semakin padat (Yuniarti, 2015). Padatnya campuran menyebabkan rongga di antara mineral agregat menjadi semakin kecil.

Sesuai dengan Tabel 5 dan Tabel 6, penggunaan bahan peremaja minyak jelantah, minyak tanah dan oli bekas serta resin epoxy menghasilkan nilai VFB yang lebih besar dibandingkan dengan nilai VFB pada aspal tua. VFB adalah prosentase rongga yang terisi aspal dalam VMA. Dengan penggunaan bahan peremaja, aspal yang telah rapuh dapat menjadi elastis kembali (Yuniarti, 2013). Aspal yang bersifat elastis lebih mampu menyelimuti dan mengikat agregat dengan baik sehingga memperkecil rongga yang secara otomatis menghasilkan selimut aspal dengan prosentase yang lebih besar. Adapun nilai density (kepadatan) yang dihasilkan pada 
seluruh campuran yang menggunakan bahan peremaja berbanding terbalik dengan nilai VIM. Semakin padat campuran yang terbentuk, maka rongga dalam campuran semakin kecil (Yuniarti, 2018). Pada campuran dengan bahan peremaja minyak jelantah, nilai VIM sebesar 5.38\%-4.85\% memiliki kepadatan 2.48-2.509 gr/ $\mathrm{cm}^{3}$, sedangkan campuran dengan peremaja resin epoxy yang menghasilkan VIM sebesar 4.6\%-3.52\% memiliki kepadatan 2.458-2.485 $\mathrm{gr} / \mathrm{cm}^{3}$. Adapun campuran dengan peremaja minyak tanah dan oli bekas menghasilkan nilai VIM dan kepadatan masing-masing sebesar 4.29\%-4.11\% dan 2.483-2.502 gr/ $\mathrm{cm}^{3}$.

Stabilitas Marshall merupakan kemampuan lapis perkerasan untuk menahan beban lalu lintas tanpa menimbulkan perubahan bentuk tetap (permanent deformation). Terkait dengan parameter tersebut, Marshall immersion adalah stabilitas Marshall pada campuran aspalagregat yang direndam pada suhu $60^{\circ} \mathrm{C}$ selama 24 jam (Direktorat Jenderal Bina Marga, 2018). Marshall immersion merupakan tolok ukur daya tahan campuran terhadap rendaman air yang menentukan durabilitas lapisan perkerasan jalan (Epps et al., 2000). Berdasarkan Tabel 5 terlihat bahwa nilai Marshall immersion pada aspal yang dioven selama 120 jam pada suhu $85^{\circ} \mathrm{C}$ lebih rendah dibandingkan nilai Marshall immersion pada campuran menggunakan aspal 60/70. Hal ini berarti bahwa campuran yang menggunakan aspal tua lebih rentan untuk mengalami kerusakan terhadap rendaman air. Penggunaan bahan peremaja minyak jelantah, minyak tanah dan oli bekas serta resin epoxy pada aspal tua menghasilkan campuran asphalt concrete wearing course dengan nilai Marshall immersion yang lebih tinggi daripada campuran menggunakan aspal tua sebagaimana yang disajikan pada Tabel 5 dan Tabel 6. Dari Tabel 6 terlihat pula bahwa penggunaan $2.5 \%$ peremaja minyak jelantah, $0.9 \%$ resin epoxy serta $6 \%$ minyak tanah dan oli bekas, diperoleh nilai Marshall immersion yang lebih besar dibandingkan dengan campuran yang menggunakan aspal 60/70. Hal tersebut mengindikasikan bahwa penggunaan bahan peremaja pada proporsi tersebut menghasilkan campuran dengan tingkat keawetan (durabilitas) yang lebih tinggi dibandingkan dengan campuran yang menggunakan aspal 60/70.

Adapun hubungan antara nilai VIM, VMA dan VFB terhadap Marshall immersion disajikan pada Gambar 1 sampai dengan Gambar 3 berikut.

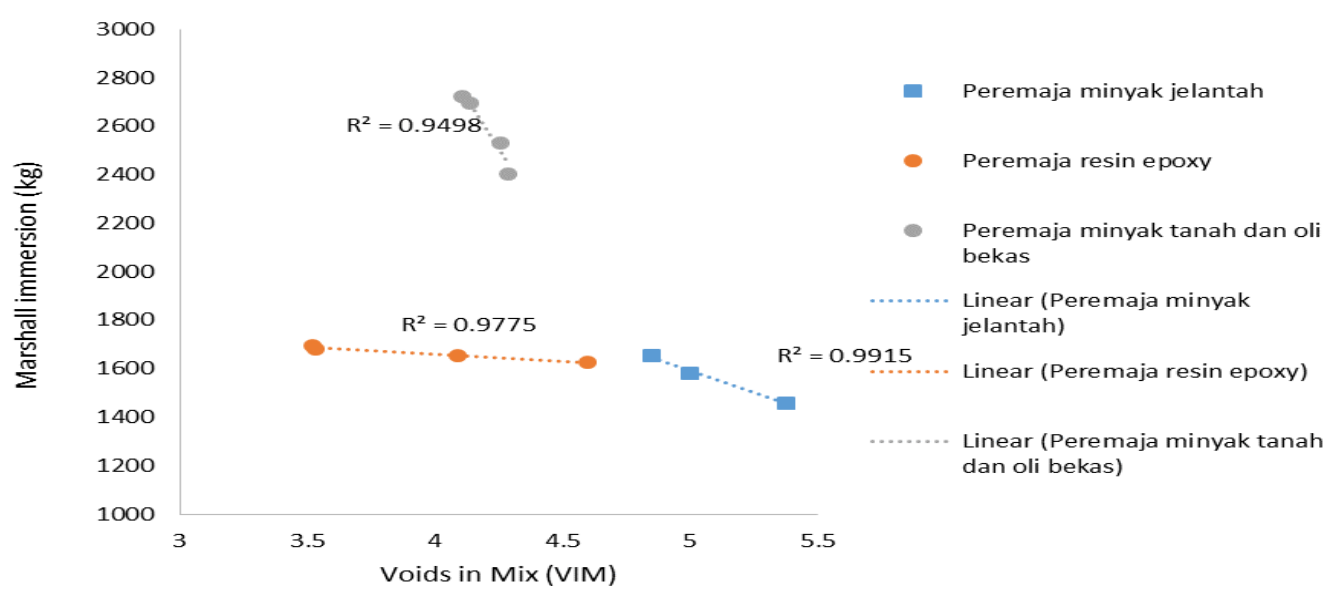

Gambar 1. Hubungan nilai VIM dengan Marshall immersion 


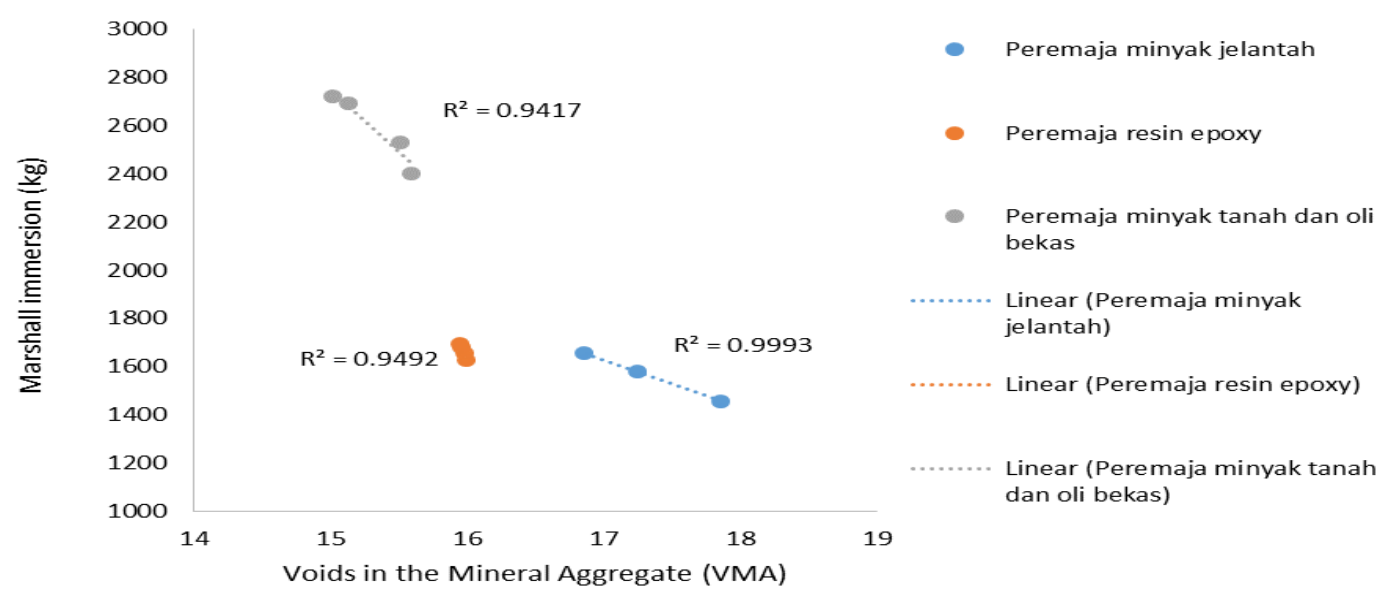

Gambar 2. Hubungan nilai VMA dengan Marshall immersion

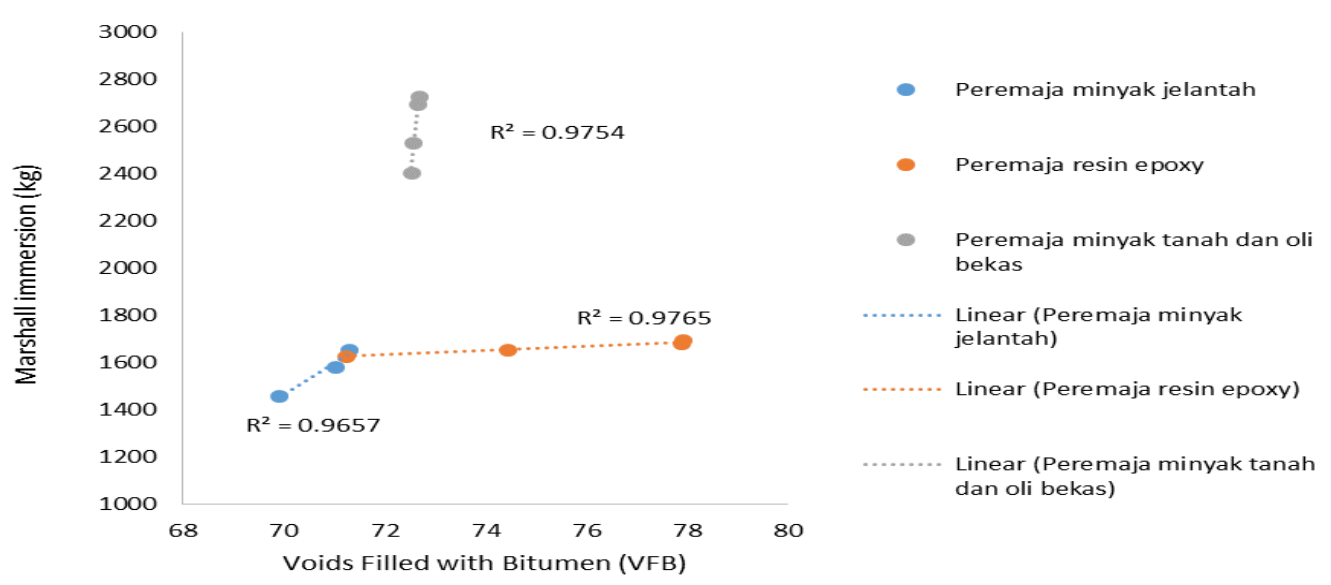

Gambar 3. Hubungan nilai VFB dengan Marshall immersion

Gambar 1 menunjukkan hubungan antara nilai VIM dengan Marshall immersion untuk masing-masing bahan peremaja. Berdasarkan gambar tersebut, terlihat bahwa semakin besar nilai VIM, maka Marshall immersion semakin kecil. Hal ini disebabkan karena pada campuran perkerasan dengan rongga udara yang besar, ikatan yang terjadi antara partikel-partikel agregat tidak terlalu kuat sehingga daya tahan terhadap pembebanan juga lebih kecil. Rongga udara yang besar secara otomatis akan menghasilkan permeabilitas yang lebih besar. (Hassan et al., 2016). Rembesan air lebih mudah meresap masuk ke dalam rongga pori dan berpotensi menimbulkan pengelupasan selimut aspal sehingga memperkecil nilai Marshall immersion. Dari Gambar 1 terlihat bahwa nilai $\mathrm{R}^{2}$ untuk seluruh bahan peremaja lebih besar dari 0.9 yang menunjukkan bahwa nilai VIM dan Marshall immersion memiliki hubungan sangat kuat dan lebih dari 90\% nilai Marshall immersion dipengaruhi oleh nilai VIM.

Hubungan antara nilai VMA dengan Marshall immersion disajikan pada Gambar 2. Dari Gambar 2 terlihat bahwa semakin besar nilai VMA, Marshall immersion semakin kecil. Fenomena ini memiliki kecenderungan yang sama dengan Gambar 1. Rongga di antara mineral agregat yang semakin besar menghasilkan permeabilitas yang besar pula (Mohammad et al., 2003). Rembesan air akibat besarnya rongga di antara mineral agregat akan mengurangi daya 
tahan dan keawetan campuran perkerasan tersebut. Nilai $\mathrm{R}^{2}$ yang berada pada rentang 0.9417 sampai dengan 0.9993 menunjukkan bahwa rongga di antara mineral agregat berpengaruh sangat signifikan terhadap Marshall immersion.

Gambar 3 menunjukkan hubungan antara VFB dengan Marshall immersion, di mana semakin besar nilai VFB maka Marshall immersion semakin besar. Sebagaimana yang diuraikan sebelumnya, VFB adalah prosentase rongga yang terselimuti aspal dalam VMA. Semakin besar rongga yang diisi aspal, maka selimut aspal makin tebal sehingga ikatan antara partikel agregat lebih kuat yang berakibat pada beban yang dapat dipikul oleh perkerasan sebelum mencapai keruntuhan menjadi lebih tinggi. Semakin besar rongga yang terisi aspal maka permeabilitas menjadi lebih kecil (Gogula et al., 2004). Selimut aspal yang tebal mengakibatkan daya tahan campuran perkerasan terhadap rendaman dalam air juga lebih besar. Pada seluruh bahan peremaja yang digunakan, nilai $\mathrm{R}^{2}$ lebih besar dari 0.9 yang berarti bahwa nilai VFB memiliki pengaruh yang sangat kuat terhadap Marshall immersion.

Hubungan antara density (kepadatan) dengan Marshall immersion disajikan pada Gambar 4 berikut:

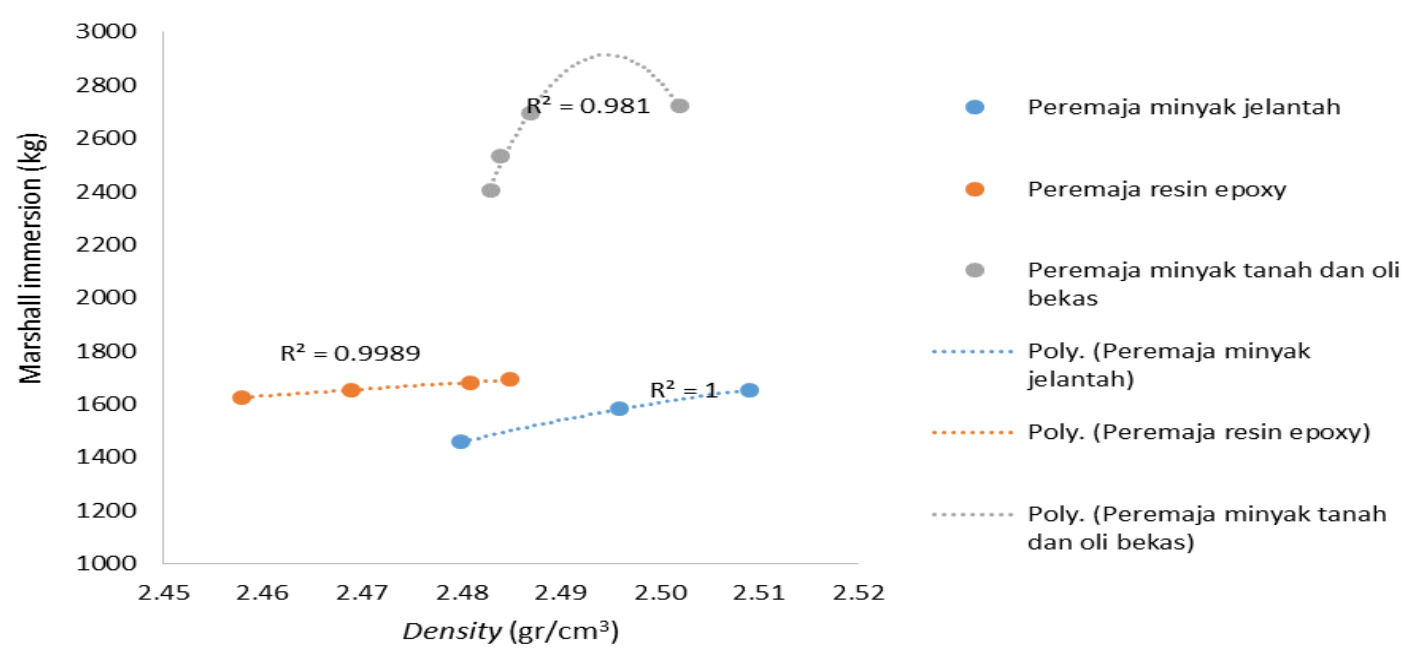

Gambar 4. Hubungan nilai density dengan Marshall immersion

Berdasarkan Gambar 4, terlihat bahwa semakin besar nilai density maka Marshall immersion semakin besar. Pada campuran dengan kepadatan yang tinggi, daya ikat antara partikel-partikel agregat lebih besar sehingga kemampuan untuk memikul beban juga lebih tinggi (Cooley et al., 2001). Semakin besar nilai Marshall immersion, durabilitas campuran ketika terendam dalam air juga lebih baik. Kepadatan campuran berpengaruh sangat signifikan terhadap nilai Marshall immersion pada seluruh bahan peremaja yang digunakan.

Berdasarkan hasil uji tersebut, penggunaan bahan peremaja minyak jelantah, minyak tanah dan oli bekas serta resin epoxy dapat meningkatkan durabilitas dari campuran aspal yang telah mengalami penuaan. Dari Tabel 5 dan Tabel 6 serta Gambar 1 sampai dengan Gambar 4, terlihat bahwa bahan peremaja minyak tanah dan oli bekas menghasilkan nilai Marshall immersion yang lebih tinggi dibandingkan dengan peremaja minyak jelantah dan resin epoxy. 


\section{KESIMPULAN}

Dari pembahasan yang telah dilakukan, dapat ditarik kesimpulan bahwa penggunaan bahan peremaja minyak jelantah, minyak tanah dan oli bekas serta resin epoxy dapat mengembalikan sifat fisik aspal 60/70 yang telah mengalami penuaan akibat pemanasan selama 120 jam pada suhu $85{ }^{\circ} \mathrm{C}$. Campuran perkerasan asphalt concrete wearing course menggunakan aspal tua yang diremajakan dengan bahan peremaja tersebut memenuhi persyaratan nilai rongga dalam campuran (VIM), rongga di antara mineral agregat (VMA) dan rongga yang terisi aspal (VFB) serta menghasilkan nilai Marshall immersion yang lebih tinggi dibandingkan dengan campuran yang menggunakan aspal tua. Penggunaan $2.5 \%$ peremaja minyak jelantah, $6 \%$ minyak tanah dan oli bekas serta $0.9 \%$ resin epoxy pada aspal tua menghasilkan durabilitas (keawetan) yang lebih besar dibandingkan dengan campuran yang menggunakan aspal 60/70. Di samping itu, bahan peremaja minyak tanah dan oli bekas menghasilkan nilai Marshall immersion yang lebih tinggi dibandingkan dengan peremaja minyak jelantah dan resin epoxy.

\section{Ucapan Terimakasih}

Ucapan terima kasih disampaikan kepada Sdri. Aisyah Ashri Huriyati, Baiq Windi Fathiah dan Siti Haifa'Mudrikah Pratiwi atas data-data penunjang sehingga tersusunnya artikel ini.

\section{DAFTAR PUSTAKA}

Ahmad, K.A; Abdullah, M.E.; Hassan, N.A.; Usman, N.; Ambak, K., 2017. Investigating the Feasibility of Using Jatropha Curcas Oil (JCO) as Bio Based Rejuvenator in Reclaimed Asphalt Pavement (RAP), MATECWeb of Conferences, EDP Sciences.

Asli, H.; Ahmadinia, E.; Zargar, M.; Karim, M.R., 2012. Investigation on Physical Properties of Waste Cooking Oil-Rejuvenated Bitumen Binder, Construction and Building Materials, 37:398-405.

Bailey, H. and Philips, P., 2010. Asphalt Rejuvenation, United Kingdom Patent Application GB 2462371 A.

Brown, S. F., and Scholz, T. V., 2000. Development of Laboratory Protocols for the Aging of Asphalt Mixtures, 2nd Eurasphalt and Eurobitume Congress, 1: 83-90,

Chen, L., Qian, Z. D., and Luo, S., 2010. Experimental Study on Dynamic Modulus of Thermosetting Epoxy Asphalt Mixturefor Steel Deck Pavement, Journal of Southeast University, 26(1): 112-116.

Cong, P.; Chen, S.; Yu, J.; and Chen, H., 2011. Compatibility and Mechanical Properties of Epoxy Resin Modified Asphalt Binders, International Journal of Pavement Research and Technology, 4(2): 118-123.

Cooley, L.A., Brown, E.R. and Maghsoodloo, S., 2001. Developing Critical Field Permeability and Pavement Density Values for Coarse-Graded Superpave Pavements, Transportation Research Record, Journal of the Transportation Research Board, Paper No. 01-0344: 41-49. 
Direktorat Jenderal Bina Marga, 2018. Spesifikasi Umum 2018 Untuk Pekerjaan Konstruksi Jalan dan Jembatan, Jakarta.

Epps, J. A.; Sebaaly, P. E.; Penaranda, J.; Maher, M. R.; McCann, M. B. and Hand, A. J., 2000. NCHRP Report 444: Compatibility of a Test for Moisture-Induced Damage with

Superpave Volumetric Mix Design, TRB National Research Council, Washington D.C. Fathiah, B.W., 2019. Kinerja Campuran Asphalt Concrete Wearing Course Menggunakan Aspal Tua Dengan Bahan Peremaja Resin Epoxy, Tugas Akhir, Jurusan Teknik Sipil Fakultas Teknik Universitas Mataram, Mataram.

Fordyce, D. and O’Donnell, E., 1994. Bituminous Pavement Material: Their Composition and Spesification, published in Bituminous Mixtures in Road Construction, edited by Robert N. Hunter, Thomas Telford, London: 1-42.

Gogula, A.K.; Hossain, M.; Romanoschi, S.A., 2004. A Study of Factors Affecting the Permeability of Superpave Mixes in Kansas, Kansas State University, Kansas.

Hassan, N.A.; Mahmud, M.Z.H.; Ahmad, K.A.; Hainin, M.R.; Jaya, R.P. and Mashros, N., 2016. Air Voids Characterization and Permeability of Porous Asphalt Gradations Used in Different Countries, ARPN Journal of Engineering and Applied Sciences, 11(24): 14043-14047.

Huriyati, A. A., 2018. Kinerja Campuran Asphalt Concrete Wearing Course Menggunakan Aspal Tua Dengan Peremaja Minyak Jelantah dan Ekstrak Buah Mengkudu, Tugas Akhir, Jurusan Teknik Sipil Fakultas Teknik Universitas Mataram, Mataram.

Mardianus, 2013. Studi Penanganan Jalan Berdasarkan Tingkat Kerusakan Perkerasan Jalan (Studi Kasus: Jalan Kuala Dua Kabupaten Kubu Raya), Jurnal Teknik Sipil Untan, 13(1): 149-160.

Mohammad, L.N.; Herath, A. and Huang, B., 2003. Evaluation of Permeability of Superpave® Asphalt Mixtures, Transportation Research Record, Journal of the Transportation Research Board, Paper No. 03-4464: 51-58.

Porto, M.; Caputo, P.; Loise, V.; Eskandarsefat, S.; Teltayev, B.; Rossi, C.O., 2019. Bitumen and Bitumen Modification: A Review on Latest Advances, Appl. Sci., 9: 742.

Pratiwi, S.H.M., 2019. Kinerja Campuran Asphalt Concrete Wearing Course Menggunakan Aspal Tua dengan Bahan Peremaja Oli Bekas dan Minyak Tanah, Tugas Akhir, Jurusan Teknik Sipil Fakultas Teknik Universitas Mataram, Mataram.

Qian, Z.D., Luo, S., and Wang, J.W., 2007. Laboratory Evaluation of Epoxy Resin Modified Asphalt Mixtures, Journalof Southeast University, 23(1): 117-121.

Soedarmanto dan Dardak, H., 1991. Penelitian Daur Ulang Perkerasan Aspal di Pusat Litbang Jalan, Seminar on Asphalt Pavement Insitu Recycling, Jakarta.

Suroso, T.W., 2009. Meningkatkan Mutu Aspal di Perkerasan Jalan yang Telah Lapuk dengan Cara Dingin, Jurnal Jalan Jembatan, 26(1): 1-13.

Xinxin, C.; Xuejuan, C.; Boming, T.; Yuanyuan, W.; Xiaolong, L., 2018. Investigation on Possibility of Waste Vegetable Oil Rejuvenating Aged Asphalt, Appl. Sci., 8: 765. 
Yang, J., Lu, H.Z., Yuan, D.Q., 2007. Evaluation of Modification Effects of Epoxy Resin Based on Performance of Asphalt Mixtures, Journal of Southeast University, 23(1): 122-126.

Yuniarti, R., 2013. Pemanfaatan Limbah Minyak Goreng Sebagai Bahan Peremaja Aspal Lama, Jurnal Penelitian Universitas Mataram, 17(1): 84-93.

Yuniarti, R., 2014. Pengaruh Minyak Biji Nyamplung Pada Bio-Flux Oil Sebagai Modifier Asbuton Butiran Terhadap Kinerja Asbuton Campuran Panas, Jurnal Teknik Sipil ITB, 21(3): 251-258.

Yuniarti, R., 2015. Performance of Bio-Flux Oil as Modifier of Buton Granular Asphalt in Asphalt Concrete Wearing Course, Journal of JSCE (Japan Society of Civil Engineers), 3(1): 33-44.

Yuniarti, R.; Hasyim; Rohani; Anwar, S.N.R.; Saptaningtyas, R. S., 2018. Karakteristik Campuran Asphalt Concrete Wearing Course Menggunakan Aspal Modifikasi Getah Pinus dan Serbuk Limbah Kaca, Prosiding Seminar Nasional Saintek, LPPM Universitas Mataram: 474-485.

Yuniarti, R., 2019. Resistance to Degradation of Porous Asphalt Mixture Using Pine Resin as Asphalt Modifier, Jordan Journal of Civil Engineering, 13(1): 113-123. 